\title{
Bilateral Level I Lymphadenopathy in Differentiated Thyroid Carcinoma: A Case Report and Review of Literature
}

\author{
Surabhi Garg ${ }^{1}$, Loreno Enny ${ }^{2}$, V Sasi Mouli ${ }^{3}$, M Shreyamsa $^{4}$, Pooja Ramakant ${ }^{5}$, Kul Ranjan Singh $^{6}$, Anand Mishra ${ }^{7}$
}

\begin{abstract}
Lymph nodal metastases in differentiated thyroid cancers (DTC) occur in 30-90\% of all cases. ${ }^{1}$ A major question remains about the therapeutic benefits of a more or less extensive lateral lymphadenectomy as metastases to levels I and $V$ are infrequent, and extensive dissections may add to the morbidity. We herein report a case of papillary carcinoma thyroid with bilateral level I-V lymph node metastases.

Keywords: Level I nodal metastases, Lymph node, Lymph node dissection.

World Journal of Endocrine Surgery (2020): 10.5005/jp-journals-10002-1288
\end{abstract}

\section{INTRODUCTION}

Differentiated thyroid cancer (DTC) is second most common endocrine malignancy, second only to ovarian malignancy. ${ }^{1}$ Papillary thyroid cancer (PTC) accounts for about $80 \%$ of all DTC. Cervical nodal involvement are seen in PTC in $30-90 \%$ cases. The regional metastasis is most commonly in central compartment followed by the lateral compartment. Level III is most commonly involved in lateral compartment (52\%) followed by level IV (45\%), level II (30\% with Ila $30 \%$ and IIb 15\%), level V ( $25 \%$ with Va $<8 \%$ and $\mathrm{Vb} \sim 21 \%)$, and level I $(<5 \%){ }^{2}$ There is proven therapeutic role of lateral selective lymph node dissection in patients with PTC; however, its prophylactic role is still debatable. ${ }^{3}$ We herein report a patient presenting with PTC with level I lymph nodal metastases.

\section{Case Description}

A 60-year-old lady presented with history of swelling over the anterior aspect of neck since 10 years with rapid progression in size and ulceration since past 4 months. She had history of similar swelling over the anterior aspect of neck 12 years back for which she underwent surgery although no records were available. There was no history of any compressive symptoms and hyperthyroidism or hypothyroidism. On examination, she had $7.5 \times 6.5 \mathrm{~cm}$ swelling in left thyroid region with restricted mobility, bosselated surface, and a healed ulcer of size $1 \times 1 \mathrm{~cm}$ over the skin. Level I, II, III, IV, and V lymph nodes were palpated bilaterally (Figs 1 and 2). Her systemic examination was essentially normal.

Baseline blood parameters including thyroid function tests were normal. Computed tomography imaging was suggestive of a large ill-defined heterogeneously enhancing soft tissue lesion with cystic and necrotic changes measuring $76 \times 66 \times 80 \mathrm{~mm}$ with infiltration into the tracheoesophageal groove. The lesion was also seen infiltrating the overlying skin, subcutaneous tissue, strap muscles, and left sternocleidomastoid muscle, with encasement of left common carotid up to $270^{\circ}$. Multiple necrotic lymph nodes were noted in bilateral level I, II, III, IV, and V, largest measuring $20 \times 15$ $\mathrm{mm}$ (Figs 3 to 5). Fine-needle aspiration cytology was suggestive of atypical epithelial cells in papillary fragments, nuclear grooving, intranuclear pseudoinclusions, dispersed chromatin, inconspicuous nucleoli, and occasional multinucleated giant cells suggestive of PTC (Fig. 6). $\overline{{ }^{1-7} \text { Department of Endocrine Surgery, King Georges Medical University, }}$ Lucknow, Uttar Pradesh, India

Corresponding Author: Pooja Ramakant, Department of Endocrine Surgery, King Georges Medical University, Lucknow, Uttar Pradesh, India, Phone: +91 9791507780, e-mail: poojaramakant@gmail. com

How to cite this article: Garg S, Enny L, Sasi Mouli V, et al. Bilateral Level I Lymphadenopathy in Differentiated Thyroid Carcinoma: A Case Report and Review of Literature. World J Endoc Surg 2020;12(1):41-44. Source of support: Nil

Conflict of interest: None

Patient underwent completion thyroidectomy with central compartment lymph node dissection and bilateral modified radical neck dissection. Peroperatively, multiple level I, II, III, IV, V, and VI lymph nodes were enlarged-largest of size $4 \times 3 \mathrm{~cm}$. The left sternocleidomastoid was infiltrated and excised. The left common carotid artery was encased with tumor for which a subadventitial

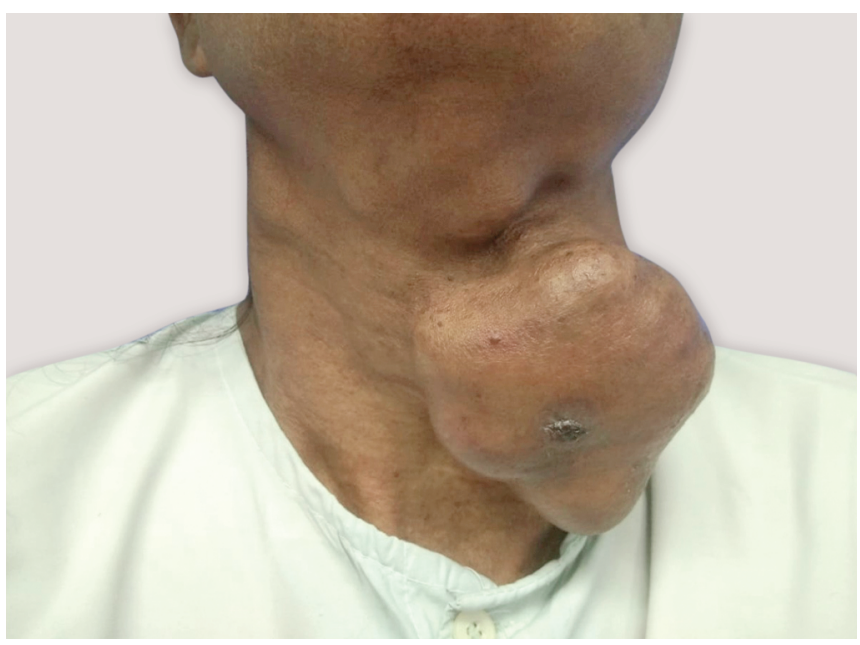

Fig. 1: Swelling in left thyroid region with restricted mobility, bosselated surface and a healed ulcer

() The Author(s). 2020 Open Access This article is distributed under the terms of the Creative Commons Attribution 4.0 International License (https://creativecommons. org/licenses/by-nc/4.0/), which permits unrestricted use, distribution, and non-commercial reproduction in any medium, provided you give appropriate credit to the original author(s) and the source, provide a link to the Creative Commons license, and indicate if changes were made. The Creative Commons Public Domain Dedication waiver (http://creativecommons.org/publicdomain/zero/1.0/) applies to the data made available in this article, unless otherwise stated. 
sharp dissection was performed. Final histopathology was suggestive of positive tumor deposits for papillary carcinoma in all 26 lymph nodes. The postoperative period was uneventful, and the
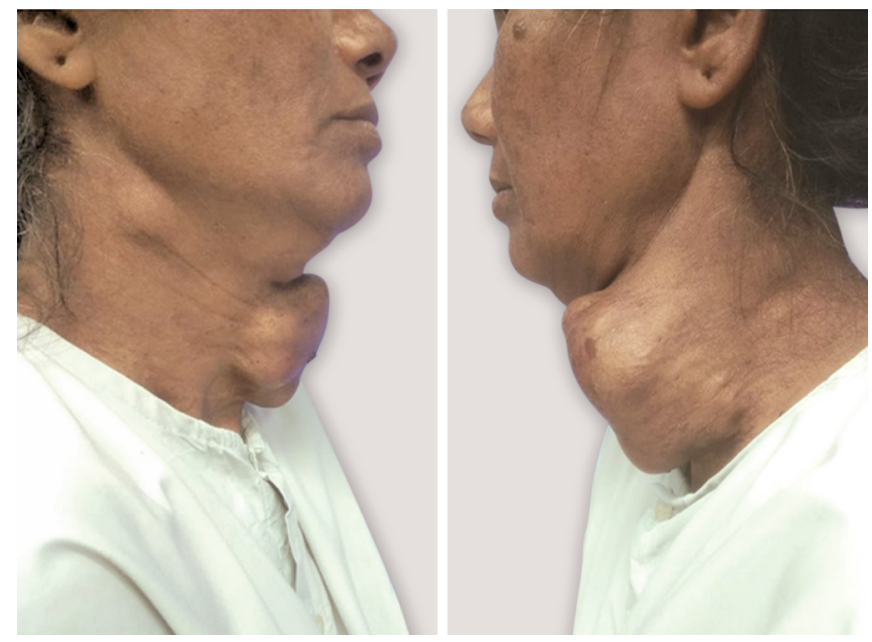

Fig. 2: Palpable levels I to V lymph nodes patient was referred to nuclear medicine for further radio-iodine ablation therapy.

\section{Discussion}

American Thyroid Association Guidelines 2015 for management of DTC state that therapeutic lateral neck compartmental lymph node dissection should be performed for patients with biopsyproven metastatic lateral neck nodes. ${ }^{4}$ Sivanandan et al. ${ }^{5}$ were the first to describe the lateral neck levels that are commonly involved in PTC, where level III was the most commonly involved and level I was the least commonly involved. Studies by Kupferman et al. ${ }^{6}$ and Sivanandan et al. ${ }^{5}$ suggested routine comprehensive neck dissection for regional metastasis and Caron et al. ${ }^{7}$ proposed that selective neck dissection of levels III and IV in the appropriate patient is sufficient when other nodes were clinically negative.

Eweida et al. ${ }^{8}$ conducted a prospective study on level I lymph node involvement in patients with $\mathrm{N} 1 \mathrm{~b}$ stage. The results revealed that level I was involved in $13.9 \%$ of patients. The study concluded that it was prudent to include level I in therapeutic neck dissection for N1b patients in selected cases of multiple level involvement and macroscopic extranodal invasion (Table 1).

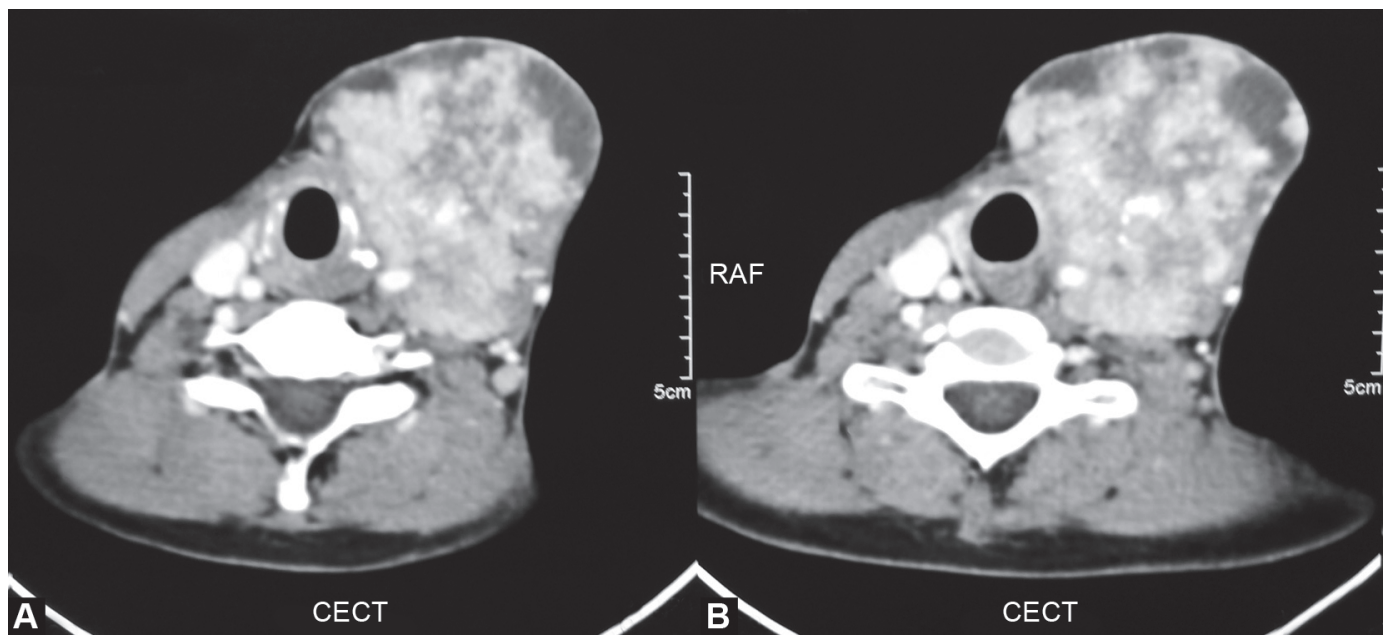

Figs $3 \mathrm{~A}$ and B: Large ill defined heterogeneously enhancing soft tissue lesion with cystic and necrotic changes

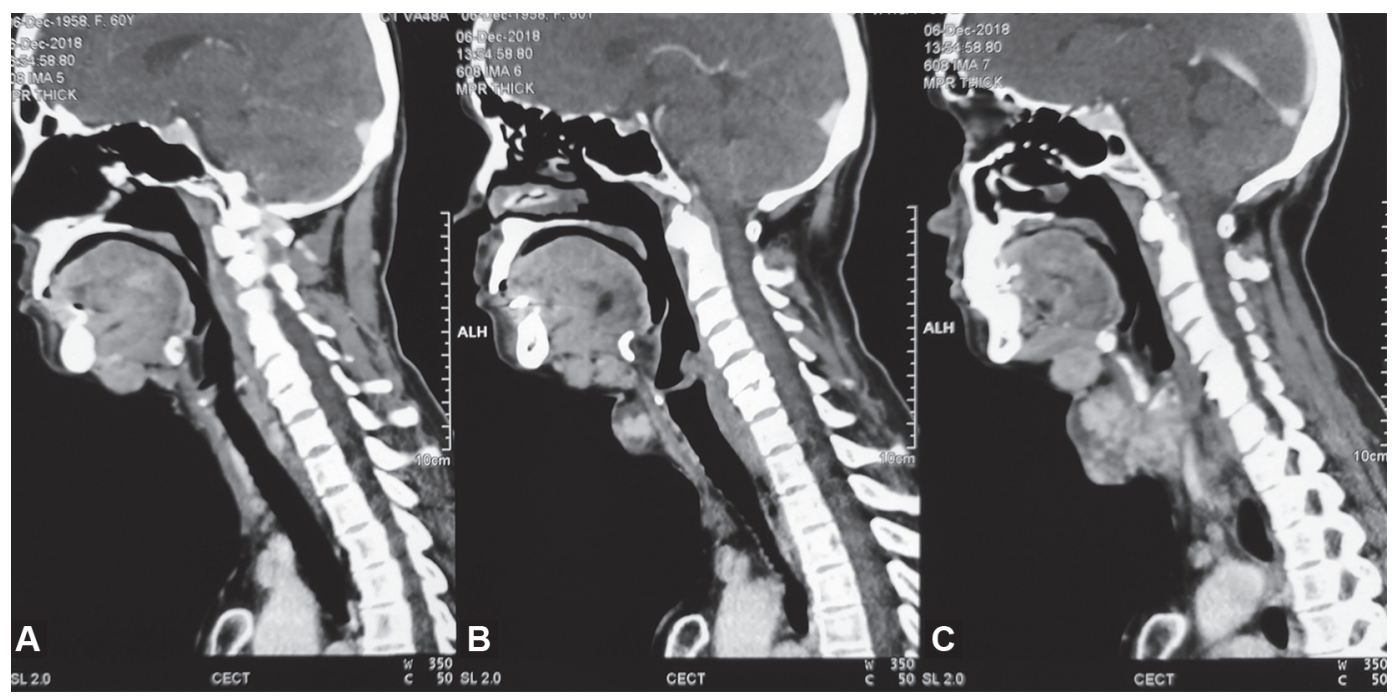

Figs 4A to C: Multiple necrotic lymph nodes in bilateral levels I to V 


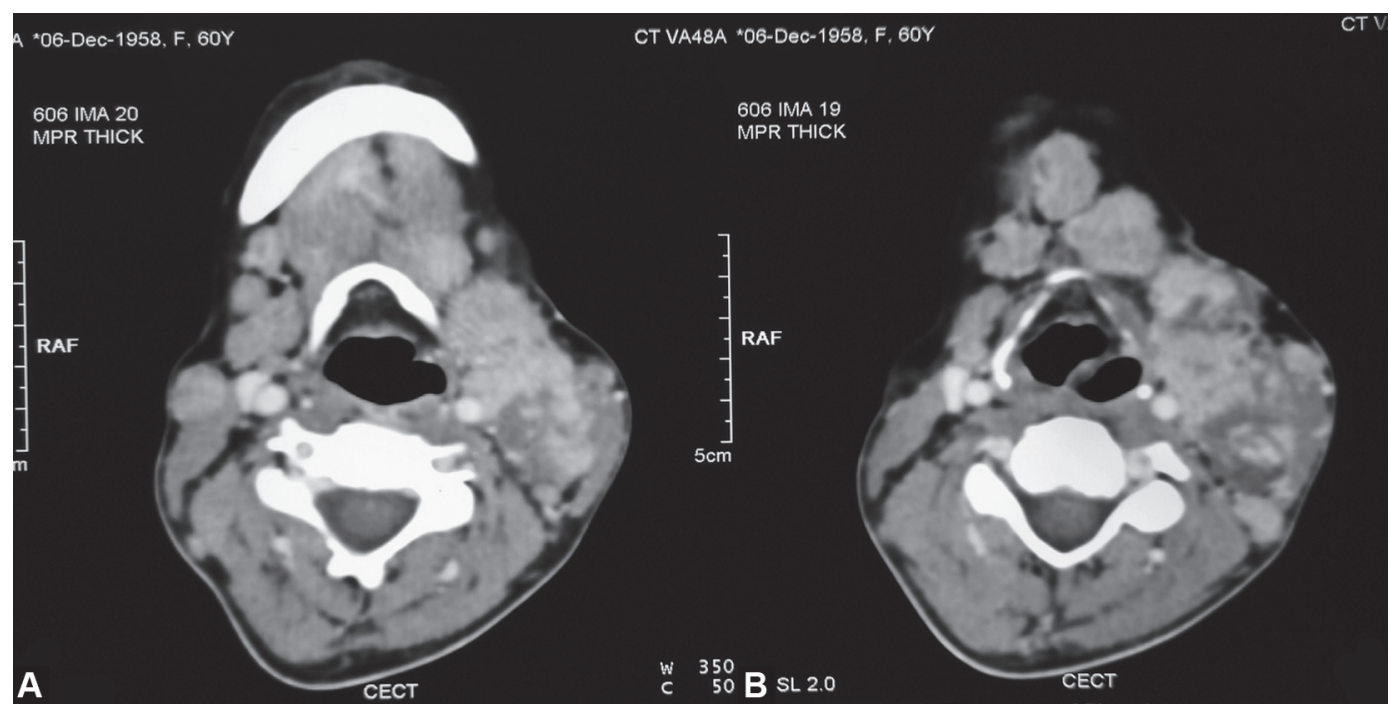

Figs $5 \mathrm{~A}$ and B: Multiple necrotic lymph nodes in bilateral levels I to V, largest $20 \times 15 \mathrm{~mm}$
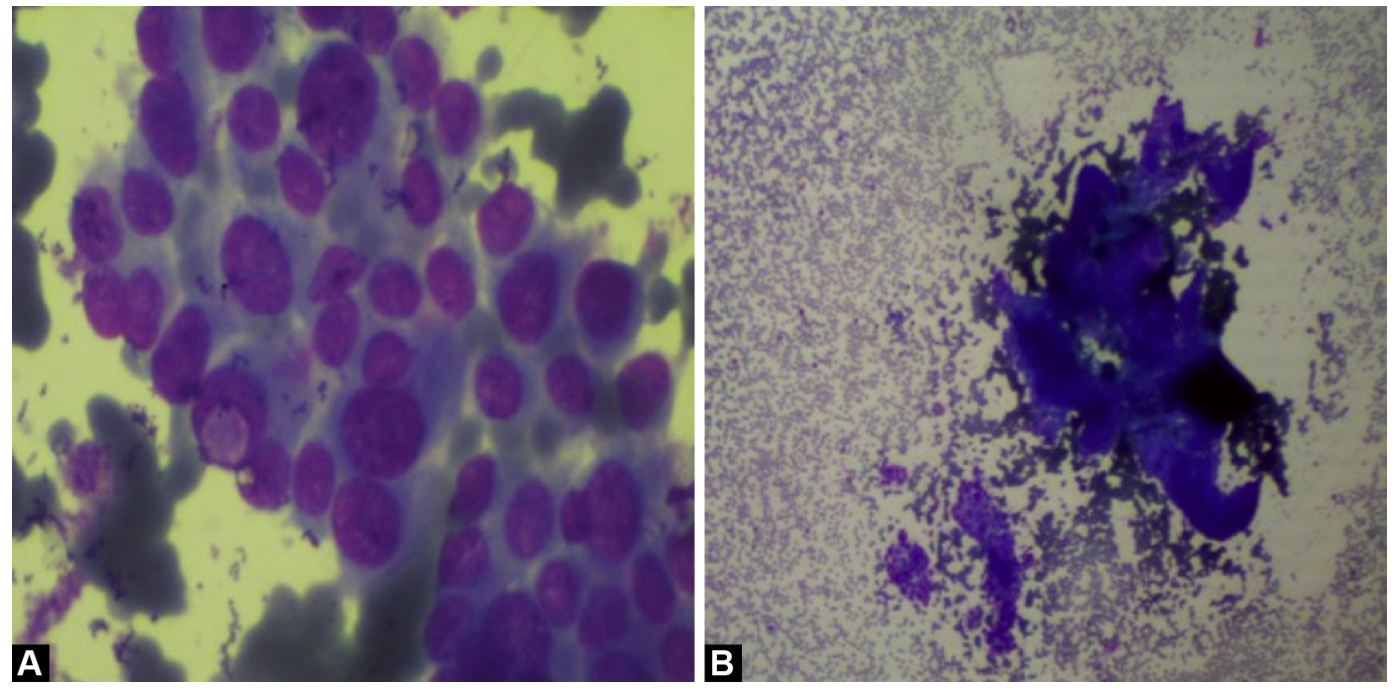

Figs 6A and B: Atypical epithelial cells in papillary fragments, nuclear grooving, intranuclear pseudoinclusions, dispersed chromatin, inconspicuous nucleoli and occasional multinucleated giant cells

Table 1: Studies pattern of lymph nodal metastasis

\begin{tabular}{|c|c|c|c|c|c|c|c|}
\hline Study & $N$ & Levell (\%) & Level II (\%) & Level III (\%) & Level IV (\%) & Level V (\%) & Level VI (\%) \\
\hline Sivanandan et al..$^{5}$ & 75 & 3.75 & 48.7 & 65 & 56.3 & 38.7 & - \\
\hline Kupferman et al. ${ }^{6}$ & 39 & 1.4 & 52 & 57 & 41 & 21 & - \\
\hline Roh et al. ${ }^{9}$ & 52 & 3.7 & 72.2 & 72.2 & 75.9 & 12.9 & 84.6 \\
\hline Eweida et al. ${ }^{8}$ & 36 & 13.9 & 52.8 & 58.3 & 58.3 & 33.3 & 63 \\
\hline \multirow[t]{2}{*}{ Caron et al. ${ }^{7}$} & 140 & 3.9 (ipsilateral side) & $\begin{array}{l}72.5 \text { (ipsilateral } \\
\text { side) }\end{array}$ & - & - & 18.6 (ipsilateral side) & - \\
\hline & & $\begin{array}{l}2.9 \text { (contralateral } \\
\text { side) }\end{array}$ & $\begin{array}{l}60.0 \text { (contralateral } \\
\text { side) }\end{array}$ & & & $\begin{array}{l}37.1 \text { (contralateral } \\
\text { side) }\end{array}$ & \\
\hline \multirow[t]{2}{*}{ Nam et al. ${ }^{10}$} & 176 & 0 (ipsilateral side) & $\begin{array}{l}40.0 \text { (ipsilateral } \\
\text { side) }\end{array}$ & $\begin{array}{l}46.0 \text { (ipsilateral } \\
\text { side) }\end{array}$ & $\begin{array}{l}42.0 \text { (ipsilateral } \\
\text { side) }\end{array}$ & 10.0 (ipsilateral side) & - \\
\hline & & $\begin{array}{l}4.2 \text { (contralateral } \\
\text { side) }\end{array}$ & $\begin{array}{l}33.3 \text { (contralateral } \\
\text { side) }\end{array}$ & $\begin{array}{l}29.2 \text { (contralat- } \\
\text { eral side) }\end{array}$ & $\begin{array}{l}25.0 \text { (contralat- } \\
\text { eral side) }\end{array}$ & $\begin{array}{l}12.5 \text { (contralateral } \\
\text { side) }\end{array}$ & \\
\hline Ahmadi et al. ${ }^{11}$ & 49 & 0 & 50 & 57 & 46 & 21 & - \\
\hline
\end{tabular}


Risk factors for level I nodal involvement do not differ from those of other lateral nodal involvement. Level I nodal involvement never occurs in isolation and is not related to any single level involvement but is significantly associated with multiple level involvements as proposed by Eweida et al. ${ }^{8}$

Caron et al. ${ }^{7}$ demonstrated recurrence at level I if previously involved to be $0 \%$ in both ipsilateral and contralateral lymph node dissections; and $1 \%$ and $6 \%$ recurrence in ipsilateral and contralateral lymph node dissections, respectively, when this level was not previously resected. The recurrence was more in patients with heavy nodal burden and extrathyroidal extensions. Ahmadi et al. ${ }^{11}$ demonstrated recurrence at level I in $3.4 \%$ of total 49 patients.

Lymph nodes 8-10 $\mathrm{mm}$ in size that can be localized on anatomic imaging may be considered targets for surgical removal. ${ }^{4}$ Crosssectional imaging helps in the identification and assessment of extranodal disease, and its relationship with the great vessels, trachea, larynx, esophagus, and neural structures. In a metaanalysis comparing the diagnostic performances of computed tomography (CT) and ultrasound for lateral cervical lymph nodes, CT and ultrasound were found to have similar sensitivities and specificities, although CT and ultrasound combined were superior to ultrasound only. ${ }^{11}$

A meta-analysis to investigate the value of central neck involvement as a predictor of lateral compartment metastasis concluded that central neck metastasis resulted in a $7.64 \%$ increased risk of lateral lymph nodal involvement. ${ }^{12}$ Metastasis in the lateral compartment reflects poorer outcomes, especially in older patients. $^{13}$

Some studies favor selective nodal dissection in the absence of clinical or radiological positive nodes, heavy nodal burden, or gross extrathyroidal extension. ${ }^{8,9,11}$ In the study by Eweida et al., $^{8}$ where the incidence of level I positive nodes was $13.9 \%$, two patients (6.7\%) experienced deviation of the angle of mouth. Marginal mandibular injury in nodal dissection involving level I reaches up to $18 \% .{ }^{14} \mathrm{~A}$ careful selection of patients requiring level I dissection is thus highly recommended to avoid unwanted complications of nerve injury.

\section{Conclusion}

Level I dissection in patients with PTC is recommended at initial nodal dissection in clinically or radiologically positive level I lymph nodes, signs of aggressive local disease (tumor subtype, local invasion, or extranodal extension).

\section{References}

1. Kebebew E, Clark OH. Differentiated thyroid cancer: "complete" rational approach. World J Surg 2000;24(8):942-951. DOI: 10.1007/ s002680010165.

2. Eskander A, Merdad M, Freeman JL, et al. Pattern of spread to the lateral neck in metastatic well-differentiated thyroid cancer: a systematic review and meta-analysis. Thyroid 2013;23(5):583-592. DOI: $10.1089 /$ thy.2012.0493.

3. Shaha AR. Prognostic factors in papillary thyroid carcinoma 17. And implications of large nodal metastasis. Surgery 2004;135(2):237-239. DOI: 10.1016/j.surg.2003.08.023.

4. Haugen BR, Alexander EK, Bible KC, et al. 2015 American thyroid association management guidelines for adult patients with thyroid nodules and differentiated thyroid cancer: the american thyroid association guidelines task force on thyroid nodules and differentiated thyroid cancer. Thyroid 2016;26(1):1-133. DOI: 10.1089/thy.2015.0020.

5. Sivanandan R, Soo KC. Pattern of cervical lymph node metastases from papillary carcinoma of the thyroid. Br J Surg 2001;88(9): 1241-1244. DOI: 10.1046/j.0007-1323.2001.01843.x.

6. Kupferman ME, Patterson M, Mandel SJ, et al. Patterns of lateral neck metastasis in papillary thyroid carcinoma. Arch Otolaryngol Head Neck Surg 2004;130(7):857-860. DOI: 10.1001/archotol.130.7.857.

7. Caron NR, Tan YY, Ogilvie JB, et al. Selective modified radical neck dissection for papillary thyroid cancer-is level I, II and V dissection always necessary? World J Surg 2006;30(5):833-840. DOI: 10.1007/ s00268-005-0358-5.

8. Eweida AM, Sakr MF, Hamza Y, et al. Level I lymph node involvement in patients with $\mathrm{N} 1 \mathrm{~b}$ papillary thyroid carcinoma: a prospective study. Eur Arch Otorhinolaryngol 2017;274(4):1951-1958. DOI: 10.1007/ s00405-016-4423-5.

9. Roh JL, Kim JM, Park Cl. Lateral cervical lymph node metastases from papillary thyroid carcinoma: pattern of nodal metastases and optimal strategy for neck dissection. Ann Surg Oncol 2008;15(4):1177-1182. DOI: 10.1245/s10434-008-9813-5.

10. Nam IC, Park JO, Joo YH, et al. Pattern and predictive factors of regional lymph node metastasis in papillary thyroid carcinoma: a prospective study. Head Neck 2013;35(1):40-45. DOI: 10.1002/hed.22903.

11. Ahmadi N, Grewal A, Davidson DJ. Patterns of cervical lymph node metastases in primary and recurrent papillary thyroid cancer. J Oncol 2011;2011:735678. DOI: 10.1155/2011/735678.

12. Suh CH, Baek JN, Choi YJ, et al. Performance of CT in the preoperative diagnosis of cervical lymph node metastasis in patients with papillary thyroid cancer: a systematic review and meta-analysis. Am J Neuroradiol 2016;38(1):154-161. DOI: 10.3174/ajnr.A4967.

13. Lan $X$, Sun $W$, Zhang $H$, et al. A meta-analysis of central lymph node metastasis for predicting lateral involvement in papillary thyroid carcinoma. Otolaryngology Head Neck Surg 2015;153(5):731-738. DOI: 10.1177/0194599815601412.

14. Batstone MD, Scott $B$, Lowe $D$, et al. Marginal mandibular nerve injury during neck dissection and its impact on patient perception of appearance. Head Neck 2009;31(5):673-678. DOI: 10.1002/hed.21013. 